


CONTAINED IN THIS
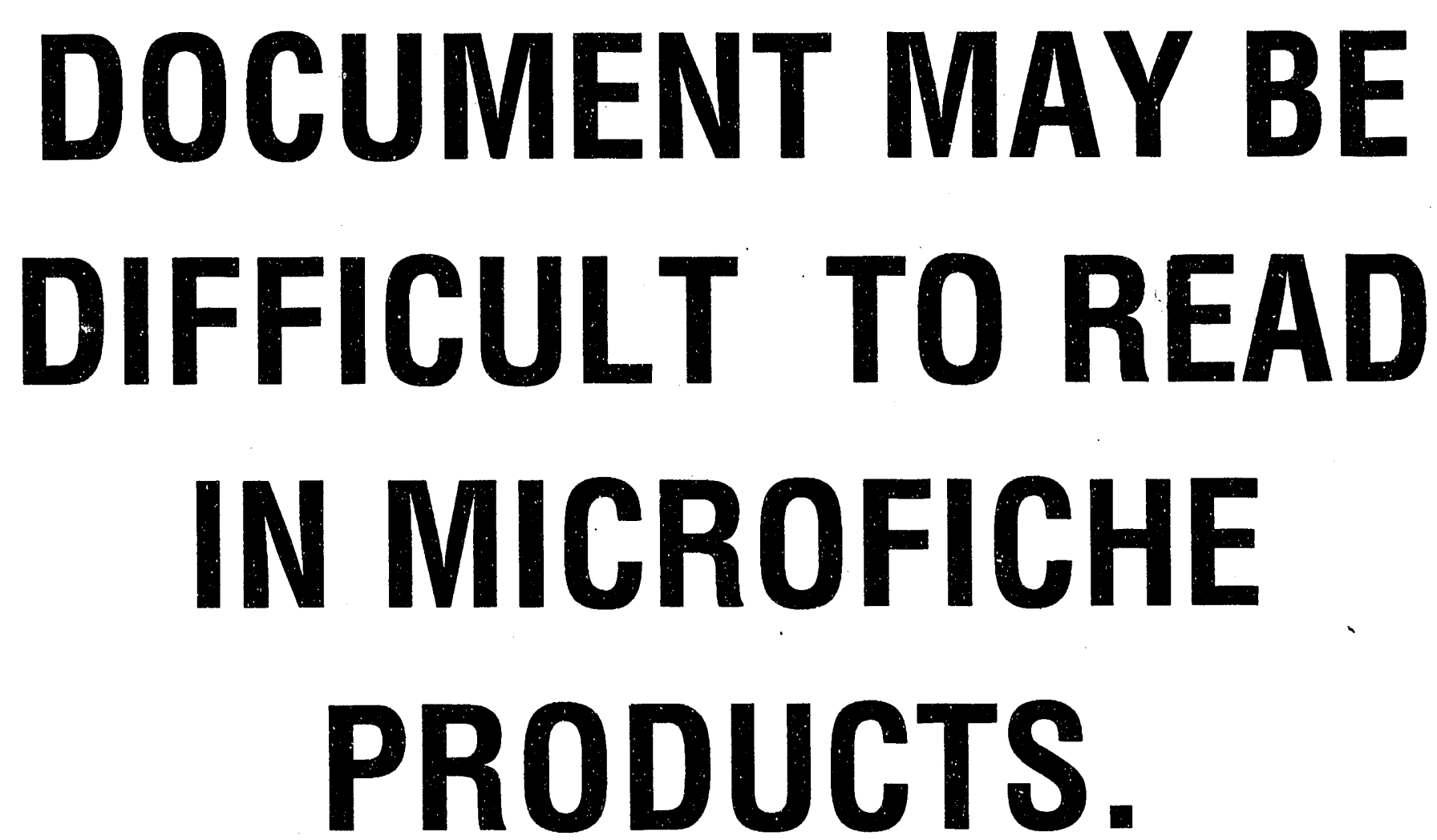


\title{
Advanced Alternate Planar Geometry Solid Oxide Fuel Cells
}

\author{
Interim Quarterly Technical.Progress Report \\ November 1, 1988 to January 31, 1989
}

By
Dave Prouse, S. Elangovan and $A$. Khandkar Ceramatec, Inc.

and

\author{
Rich Donelson and Len Marianowski \\ Institute of Gas Technology
}

Work Performed under

DoE Contract No: DE-AC 21-88MC25168

\author{
For \\ Department of Energy \\ Morgantown Energy Technology Center \\ Morgantown, WV 26505
}

\section{DISTRIBUTION OF THIS DOCUMENT IS UNLIMITED}

By

Ceramatec, Inc. 2425 South, 900 West

Salt Lake City, Utah, 84119.

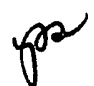

\section{DISCLAIMER}

This report was prepared as an account of work sponsored by an agensy of the United States Government. Neither the United States Government nor any agency thereof, nor any of their employees, makes any warranty, express or implied, or assumes any legal liability or responsibility for the accuracy, completeness, or usefulness of any information, apparatus, product, or process disclosed, or represents that its use would not infringe privately owned rights. Reference herein to any specific commercial product, process, or service by trade name, trademark, manufacturer, or otherwise does not necessarily constitute or imply its endorsement, recommendation, or favoring by the United States Government or any agency thereof. The views and opinions of authors expressed herein do not necessarily state or reflect those of the United States Government or any agency thereof. $\gamma \lim (n+\cdots)$

MAY 201993

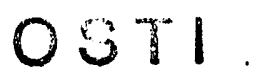






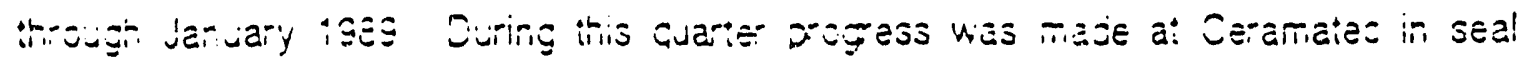

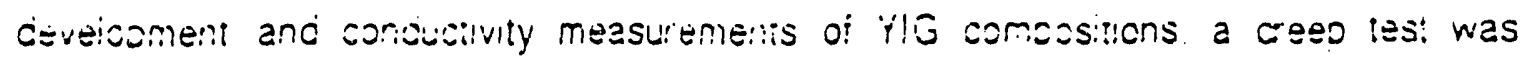
corppis:ed on the porousicenselporous tilayer IGT IGT also provicec a discussuri on


Ceramatec and!GT during this çuäiố.

\section{PROGRESS SUMMARY}

Uuring inis reporting pericc work was caried out on the toilowing tasks:

- Task 1: Ce!! Design Analysis

- Tásk 2: Program Liaison and Tes: Facilliy freparation

- Task 3: Eiectrolyte Deveiopment anc Faoricarion

- Task 4. Edge Seal Deveiopment and Fabrication

- Task 5: Electode Development and Fazrication:

- Task 6: Interconneri Developmient and Fabrication

- Task 7: Out-of-cell Tests

Tasks 8.9 and 10 were no: active during this pericd and are no: schedulad to be active unitil later in tüe project.

\section{Insk 1. Co!: Design Analusis}

Ai this point. Task 1 is essentiall:y compleite and the pressure fop for a given ceil design can now be calculated. A summary oi the results is given in the August-Octaber 1988 Quarterly Report. When new information on the design of the planar-ibbed SOFC is obtained. the program may be used.

\section{Task 2. Procam Liasson and Tes: Faglitity Preparation}

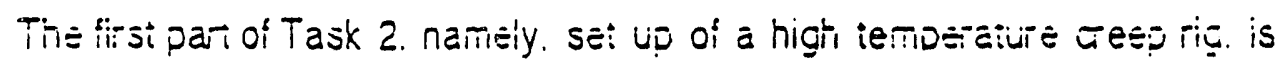
complete. This ric will aliow esting o: the materias deveiopod by

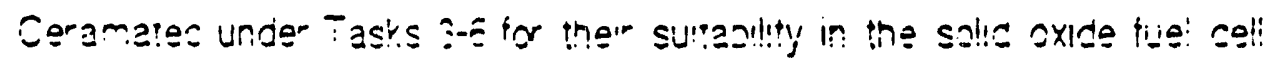


Wirr wil: ncin begn on the design of tes: rigs io ce!! sea! evaluat:an and

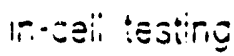

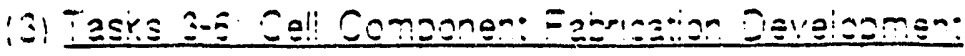


measuremer:s of copec YIE compostions Elefoce matix-electolyte

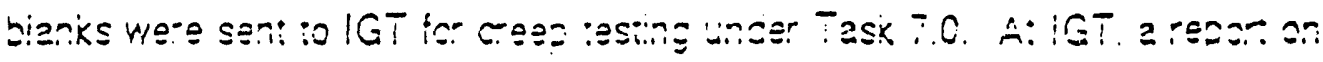


thermal expansion coefficient oi the seai sample was measured.

\section{Task 7: Out-of-sell Tests}

Samp!es of tllaye: electrolyte components were sent io IGT. One Gesp ies: has already been rur. under Task 7. Additionai tests will be run as soor as seal and electuode impregniation studies are complated.

\section{Progress at Ceramatec}

During ite later part of Noveriber Ceranates moved its Ráb labs is a rievi iocation. Tris has caused some inadvertent delay assosiated with set-up of iaboratory iaciliites in irie new locatıon. Ceramatec will make every etior: to complete ine move and bring all equipment up and in working orcer.

\section{Task 30 Eiectroivte Deveiopment and Fabrication:}

The eleztode masix-electolyte samples sintered eaplie: were inspezted for flatness and unifumity of shrinkage as well as the piesence of any delamination during the sintering process No delamination was found. These samoles were then deivered tolGTior creep iesing. The samples had unitim inickness ane area of approximately 0.25 in. $^{2}$. The zeep tes: details are induded uncer Task 7.0. Tine zyerage asep was

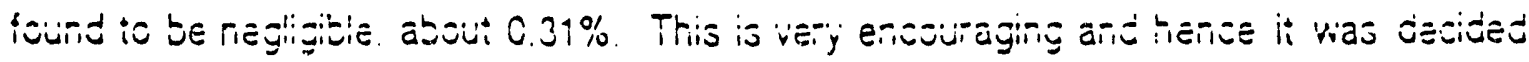
lo make more composia eiectrode marrix-eiscrolvie laps This activity was pianned for

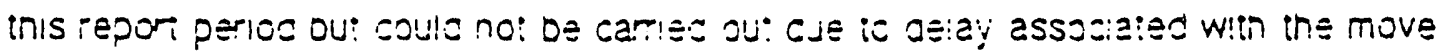




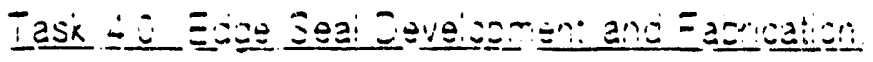

Eun a

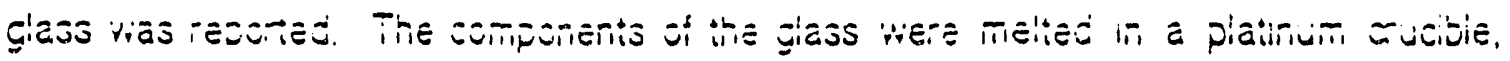

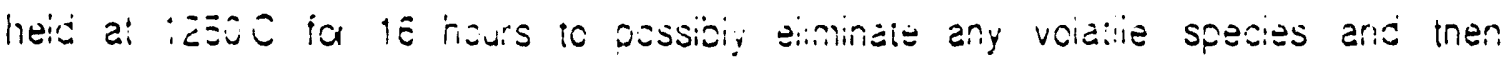

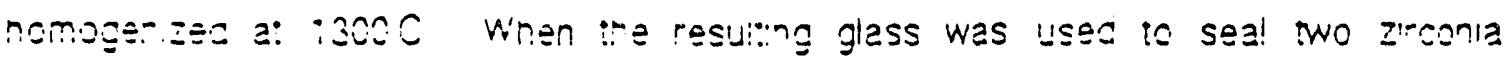

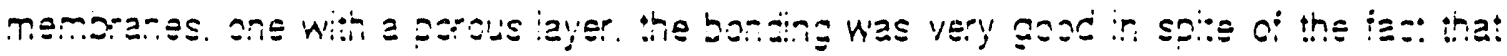

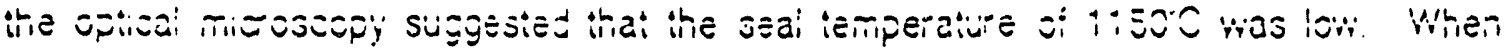
the sea: was subjected to reducing atmoschere itizl a! 10000 for one hour the seal showed some arscolciation. This has been observed in, eariler siudies of this seal material at Ceramatec. This discoloration is believed to ocsur due to the Pbo component in the glass that resuees to $\mathrm{Pb}$ in $\mathrm{H}_{2}$. However, the discoloration did nut appear to afiect effectiveness of the sealing and the same composition of giass was used successiully to seal zirconia electolyies for more than 200 hours oi continuous cperation

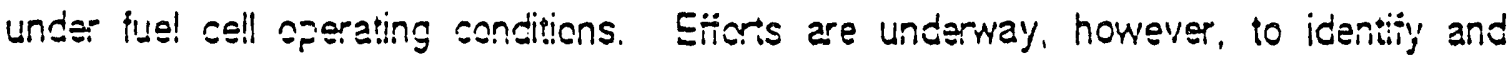
replace the Po coritaining component of the glass without compromising other characteristics.

During the processing of glass components to form the glass a sample was

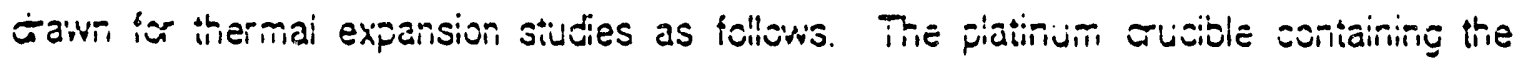
molten giass at ijô0 $\hat{C}$ was pulied out of the furnace. A stainiess siest rod (i/4 ciaj was dipped into the molien g!ass and pulled siowly at a relatıvely constant speed such that a glass rod of unitorm coss section solidifies. The roc thus formed was about 2" long and hac a diameier of ajout 1/8". The esges of the rod were polistied io give paraliel fia! surfaces. The giass rod was sent for coefficient of thermal expansion (CTE) measuremeni using a dila:ometer The dilatomejic tace is given in Figute 1 Thie race displays the differential chenge in dimension of the glass rod on heating and sasing. The glass was guvenched in air from aboui i $300^{\circ} \mathrm{C}$ in the prosess st tawing the ived. it is highiy likely thai the g!ess rod had residuai internai stresses. Tinis fact is evicenced trom in anomalous beriavior o: ine dia:ornesic race in the 550 to $500 \mathrm{C}$ range durng the hezting sycle whise negigibie or negative change in expansian is observed. It


caus:: 2 an increase in class densiy. This resuits in a cestease in samamen






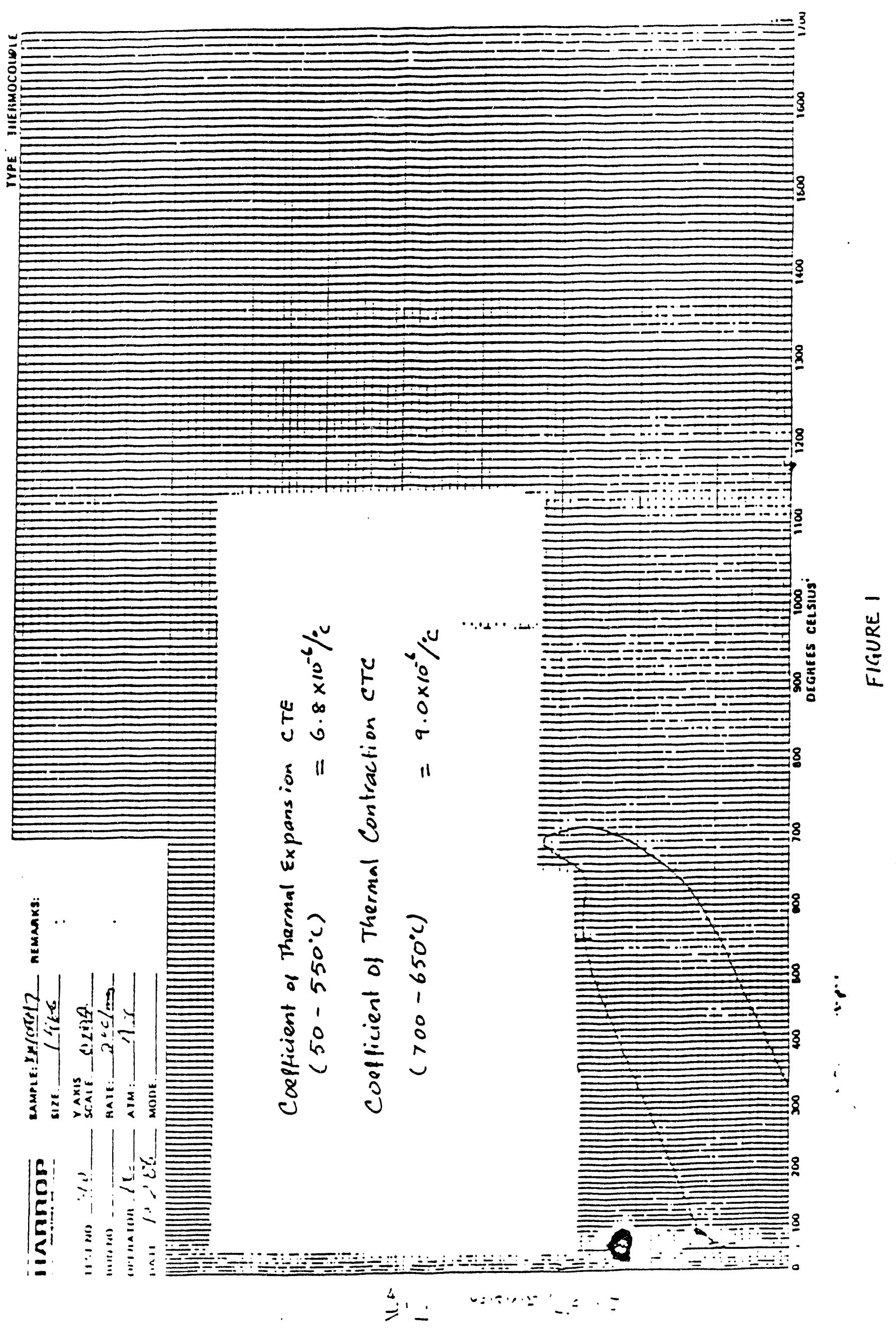




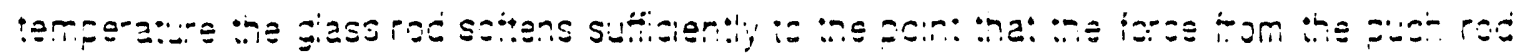

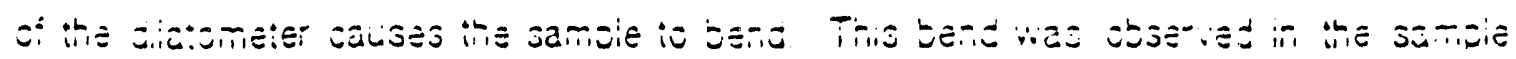



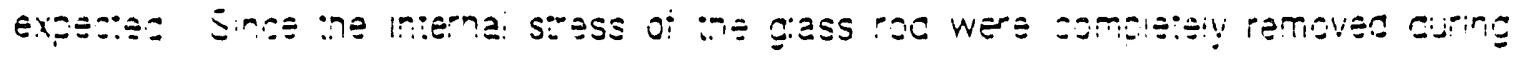

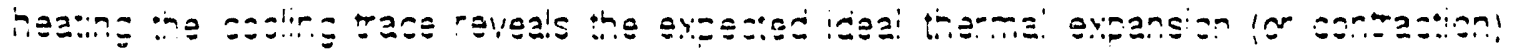



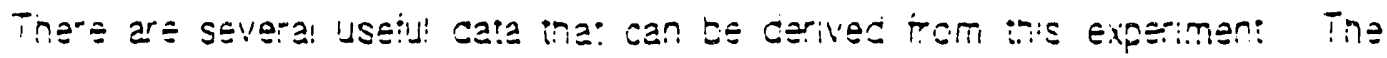

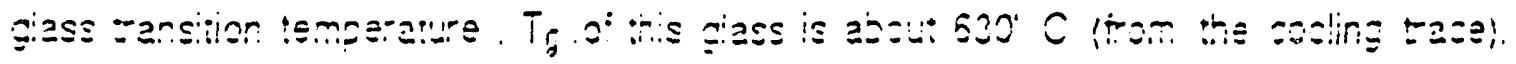

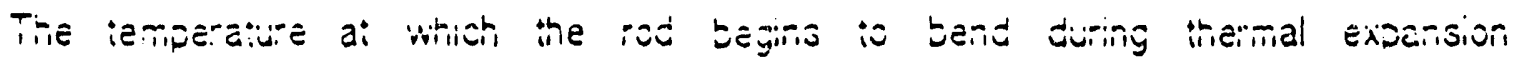
measul ement known as diatomeric offormation temperature To is abou: 650 C. The g'ass ransition temperature es:abilsnes the annealing temperature atter efieconng the seal a: abou! 600 $\mathrm{C}$. Since 690 $\mathrm{C}$ is the temperature at which the glass begins to determ under load, it is conceivable that at ihe opeiating temperature i $1000^{\circ} \mathrm{C}$ i the seal wiil be stiil more compliant. However the glass will still be confined to the joint area dus to the operating iemperature being $200-250^{\circ} \mathrm{C}$ below its working poini.

Ansther imporiant factor io consider in characterizing a seal material is its coefficient of thermal expansion (CTE). Selow $T_{g}$ the calculated value of CTE is $6.8 \times 10$ ${ }^{\circ} i^{\prime} \mathrm{C}$ and above $T_{g}$ it is $9.0 \times 10^{-6} /{ }^{\circ} \mathrm{C}$ (trom the cooling curve). The CTE tor the zurcon!a eiecsolyte materizl is $10.5 \times 10^{-6} /{ }^{\circ} \mathrm{C}$. lceally a good CTE ma:th is desired above $\mathrm{Tg}$. suth that residual süesses are not ceates when the somponenits are couled atis itie seal is effected. However, it should be remembered that giasses ca:i withstand very hich compressive stresses bui iraciure uncer low ierisi:e stess levels. Hence a glass inai has a lower CTE than zircania may s.ill iuncoicn as an effecive sea! ma:aria!. Work wi!! be coritriced to incease the CTE of the glass sloser to that of zirconia and stili mainiaining the other characieristics. Cptions to reduce or eliminate components that reduce in the tuel aimosphere are also being invesilgated.

Two aspecis of the seal development work were canted out duing the latie: part of this report period. Firstly. a wide range of ieadufree commercial giasses were consice:eu as possicle seal cancidate. Earier it was reporec ina: the curteni giass sea! ma!oria! (KWiogd7) has periorned adegya!e!y in hermetia soaing of zirzania


conditions. Ii was ojserved that cri the arods sode of the saa: the gass had blackerise

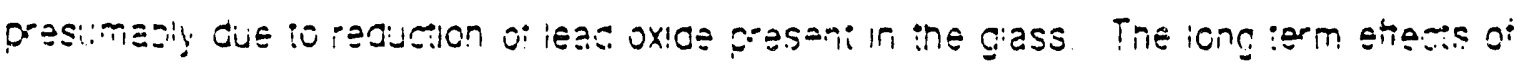








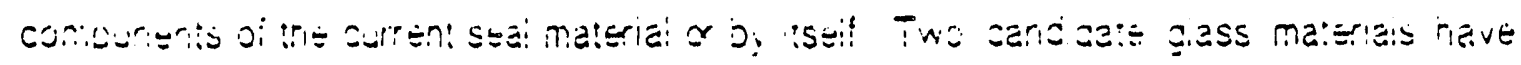

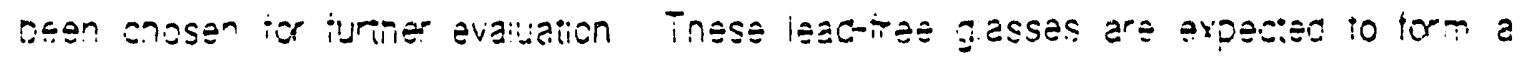

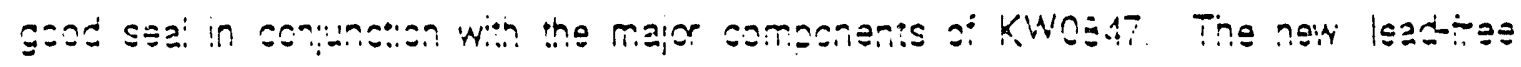
giasses chiosen aie exieacied is incosese CTC of the baseline glass in addition to frovidirg a hori-rebucing seai. Ciscussions with a commerazi vencor is curentiy Lr:coway ro zrocuro ine deslied giasses

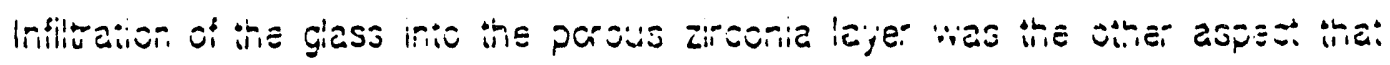
wiss investigated during this report perioc ar initial trial was cone with a siurry of giass in an croanic binder. The siurry was placed on the porous sutiace of tite porous-ciense bilayor and fired a! 1250' $\mathrm{C}$ ior 30 minutes. Optica! mirossopy of the sample revea!ec ihai the glass has roi penetated apreneziably into ihe pares. This conciusion was arived at due to the fact tha! the giass siury had not flowec appreciabiy on the surface. Even though the iring iemperarure of $1250 \mathrm{C}$ may be adequaie for sealing of two dense membranes. as evidenced trom the herneticity experimen:. it may be ton low for infiltation. Two approaches are being plarired for the nexi report period. Ir. the first one a thinner slurry will be vacuum infiltrated and fired at $1250^{\circ} \mathrm{C}$ and a second trial of vacuum infilsated glass will be ïred at a higher temperature. Options to use screen printing technique will also be investicated.

\section{Elecjoce Deveicoment and Fabrication:}

\section{(a) Eiecronizaily Conducing ZOO, Eased Biecrode Niateriais}

The maierials for the $40 / 10 ! 50$ mol\% composition in the thres phase lng $\mathrm{C}_{3-}$ PrO, i-Zro sysiem were reseived. Symitiesis of the electude will soun bejin and the materlal wili je evaiuared io concuctivity and thermal expansior characieristics.

\section{(b: Doose "e" t,os goroughtes}

No wark was cone on this sub-task durng inis reasn period. 


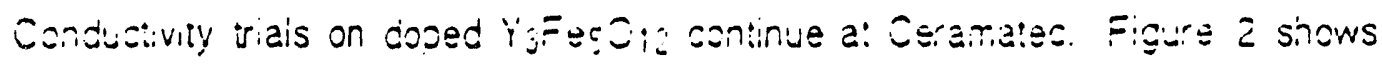

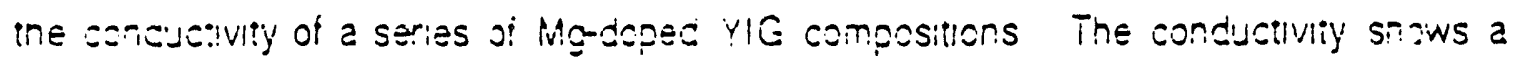

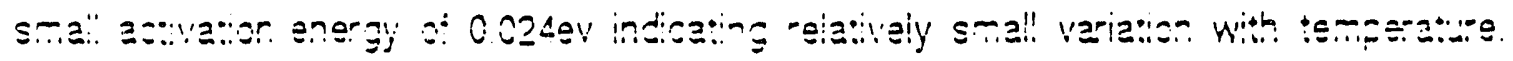

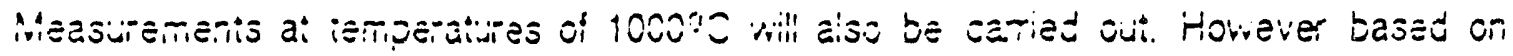

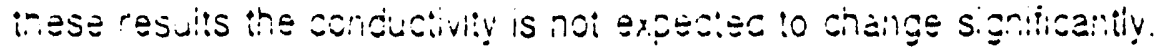

A series of Cr-dzaes YlG compas:inns were synthesized and tested tor

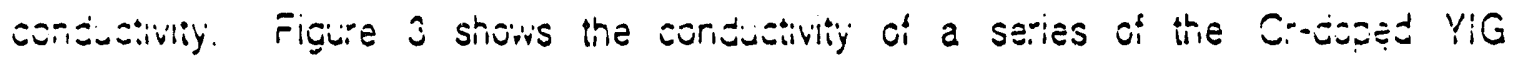
comccsitions. The conductivity shows an activation energy of $0.56 \mathrm{eV}$. Comparison of coriducilvities of ine Mg doped and ine $\mathrm{Cr}$ doped series of Y.IG materials shows that the My-ioped sories exhibit a Feater conduativity (2-6 $\times 10^{-2}$ Siem ) at $700^{\circ} \mathrm{C}$ than the Crdoped series $\left(2 \times 10^{-3}-2.5 \times 10^{-2} \mathrm{~S} / \mathrm{cm}\right)$. However the $\mathrm{Mg}$ doped YIG materials exhibit far less temperature dependence as shown in the previous report. Extrapoiation of the conductivity Dehavior of Cr-doped (see Fiqure 4) suggesis that these may have higher condustivity (4.5 $\times 10^{-2}-2 \times 10^{-1} \mathrm{~S} / \mathrm{sm}$ ) compared to the Mag-doped Y!G elestrodes. Platinum lead vires have been ordered and a couple of $\mathrm{Cr}$ and Míg dopad sampies vill be tested at $10000 \mathrm{C}$ as soon as they are received.

\subsection{Intersonnesce Develosment and Fabrication:}

Intercomes: Deveicpment and Facrication, is being carried out by Ceramatec. However. fabrication of thin, flai ceramic suruciures with flow-ile!c ribs poses very challenging rroblems. In cider io expedite cell iesting using advanced cell design and component geomeny concepts. Ceramatec ashed iGT io supply a discussicn of possible materials which could je used for an interconnect. IGT had caried out an in-depth survey on h:gn temperaiure meial alloys for use in MCFCs. Ceramates wanted to expiore the possibility of using a stamped meia! interconnest-eiectode sturture incüpurating ribs ar dimples io allow gas flow. Ceramaies aiso requesied recommencations on alternative interconnec: materials. This request was based on pror discussions ai IGT where Ma-k Lawson of IGT suggesied the possible use of Fe? $O_{3}$ as a potential interoonnes: ma:trial. Diszussions of these wi areas are given belowi. 
Conductivity of $\mathrm{Mg}$ doped $\mathrm{Ca}(0.4)-Y I G$

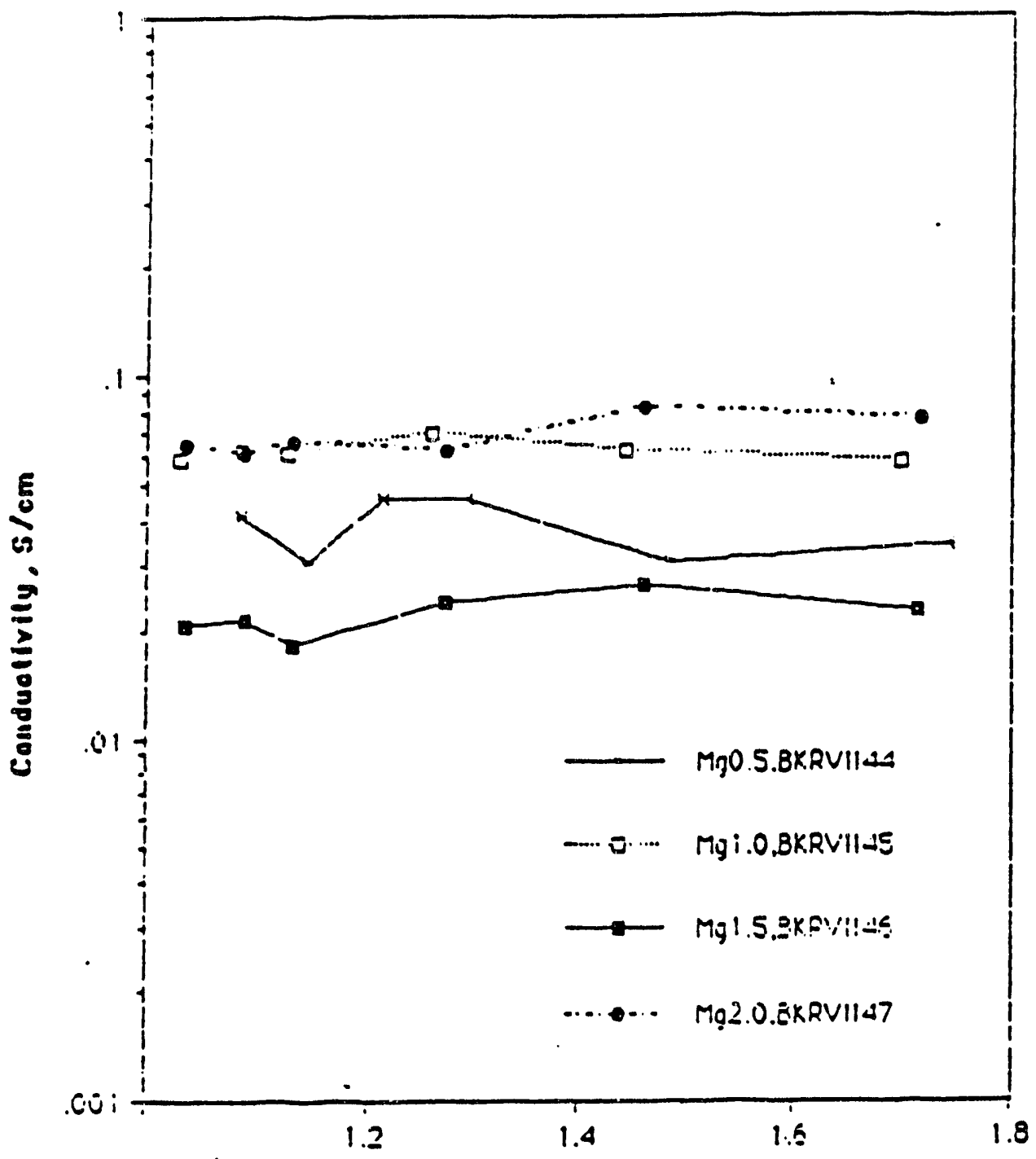

$1000 / T .(1 / X)$

Legend shows at Mg concencrations

in acom i (sample I.D. codes are also shown.) 
FIGURE 2

Conductivity of $\mathrm{Cr}$ doped $\mathrm{Ca}(0.4)-Y / G$

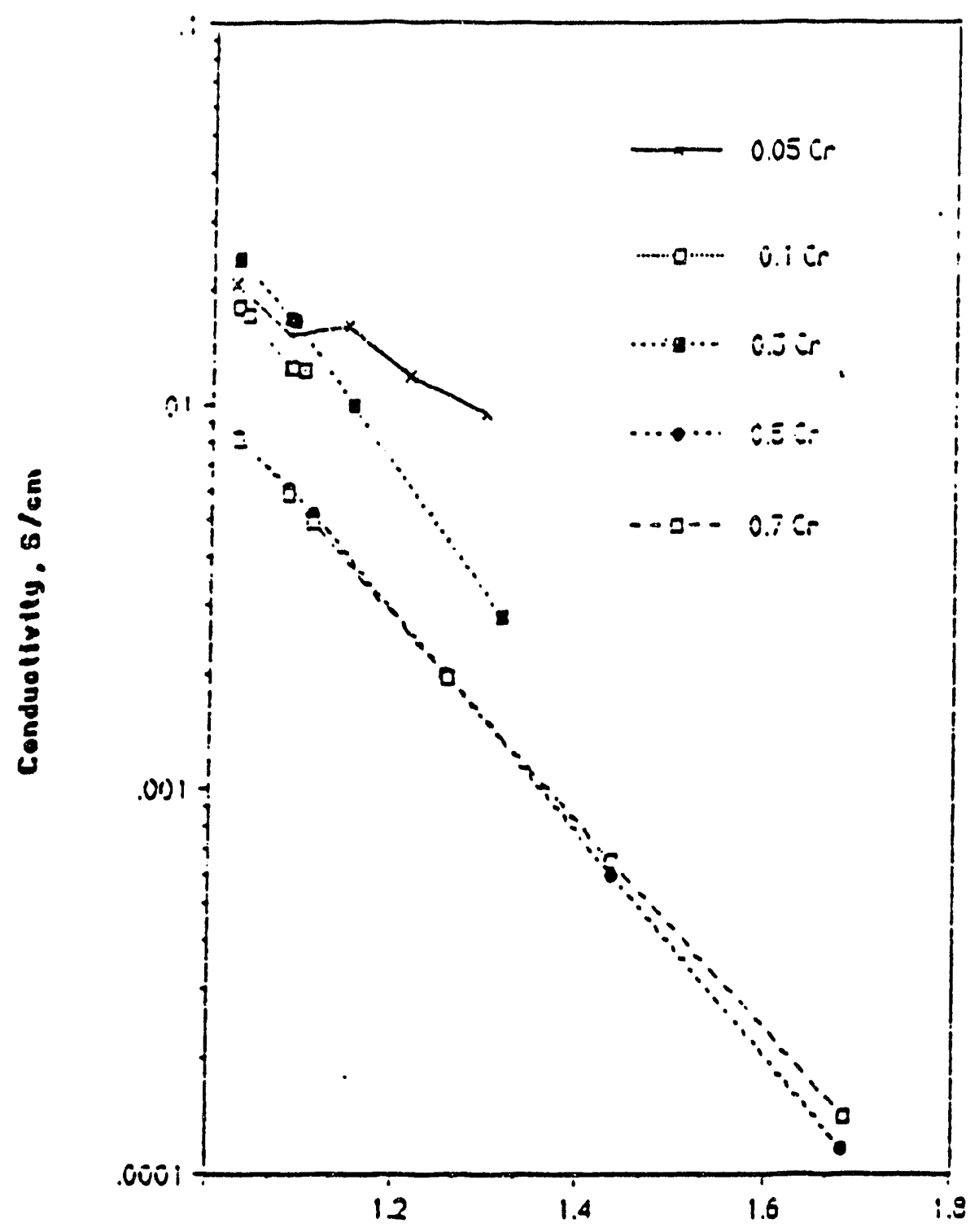

$1000 / T K$ 
EICURE 3

Projected Conductivity Behavior of Cr-doped YlG e $1000 \mathrm{C}$

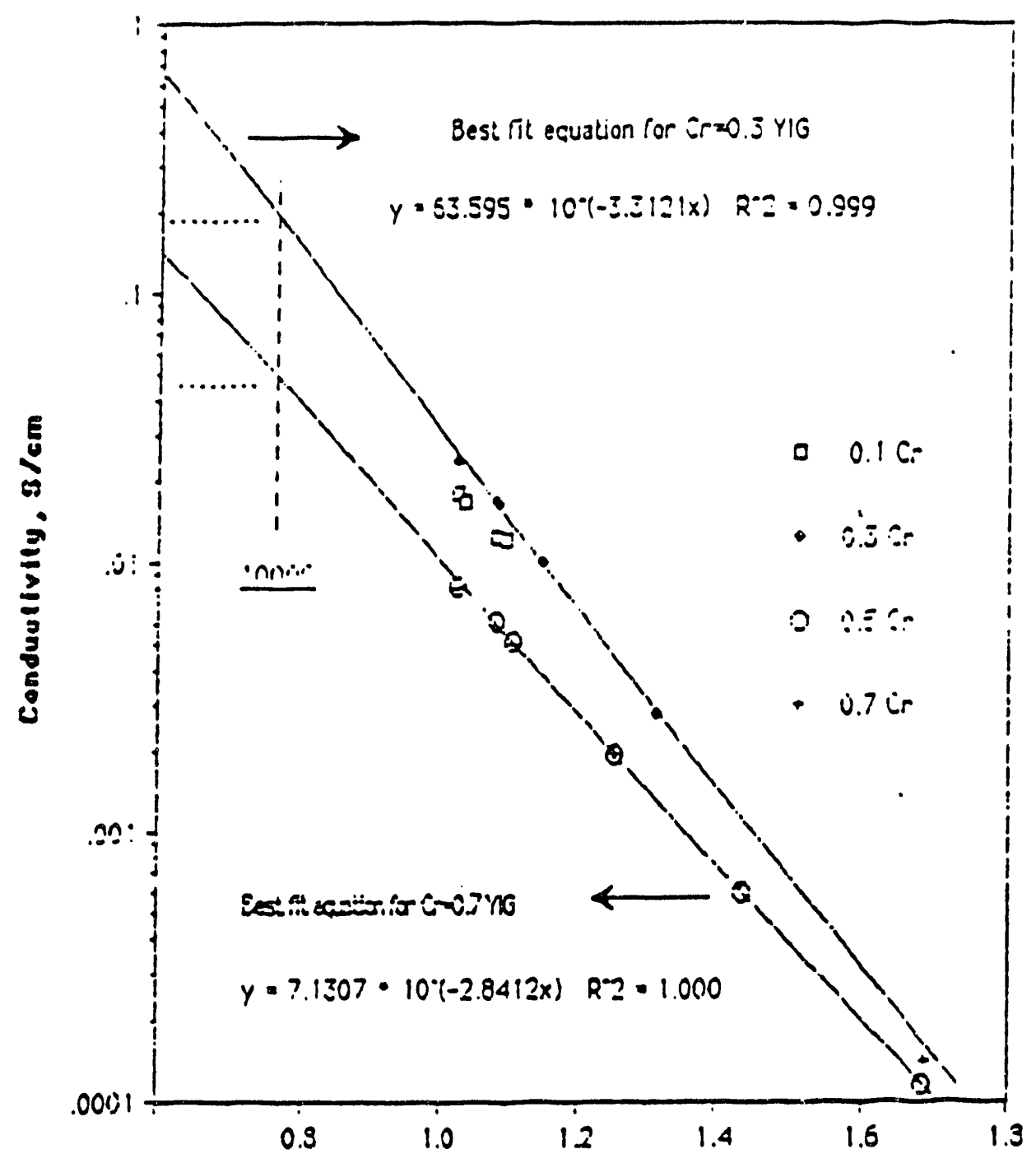

$1000 / T K$ 


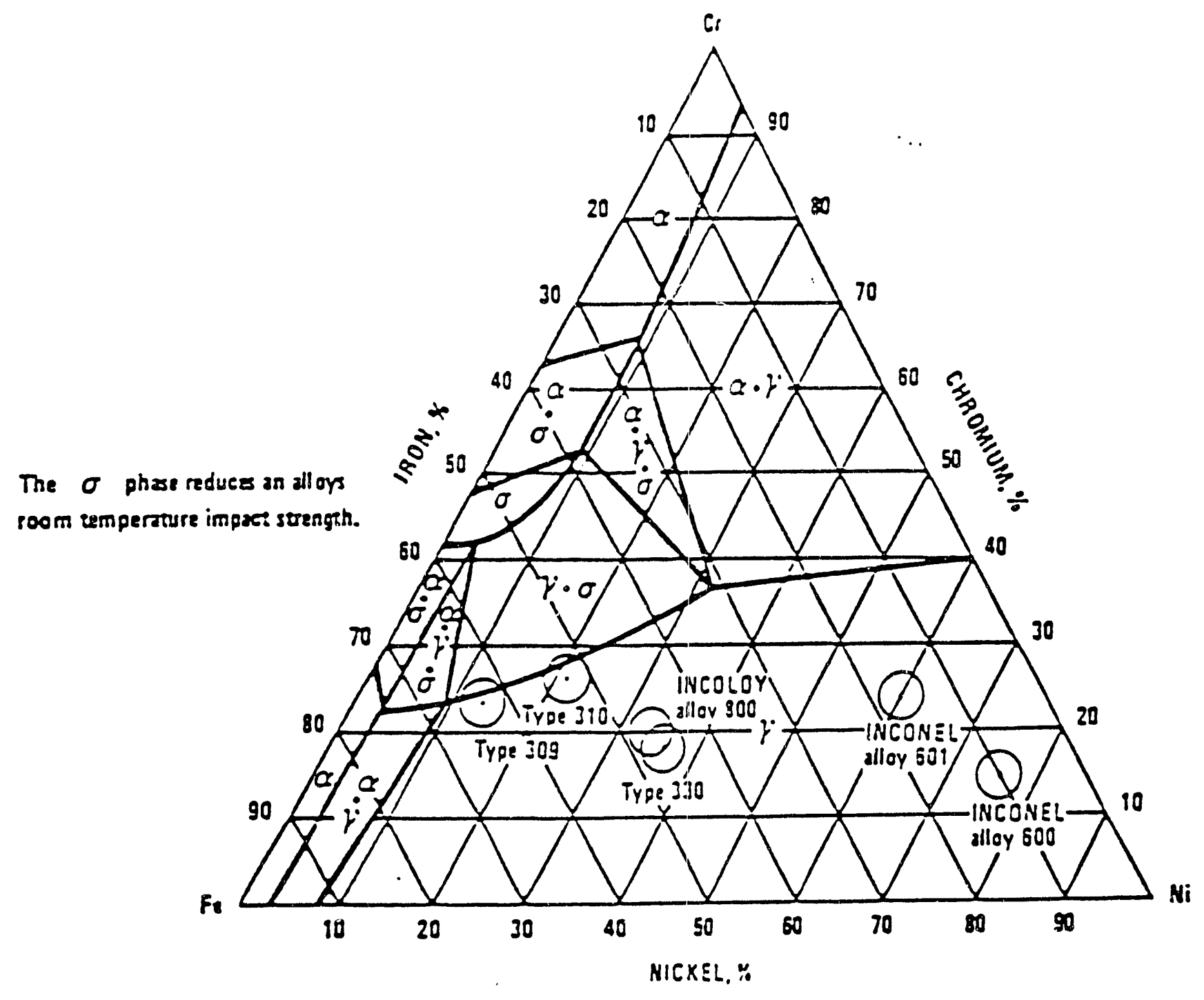

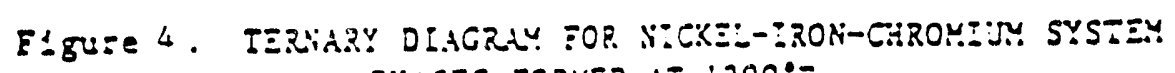
PHASES FORE JE $1200^{\circ}$

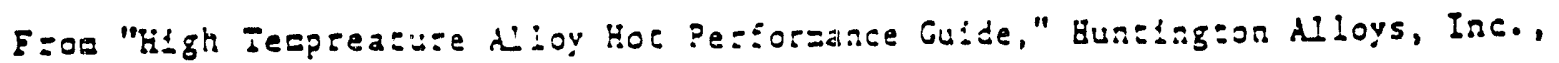

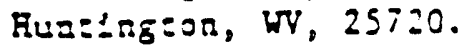




\section{CREEP STAENGTH}

(IX Mir Crep Rate/10,000 Hrs.)

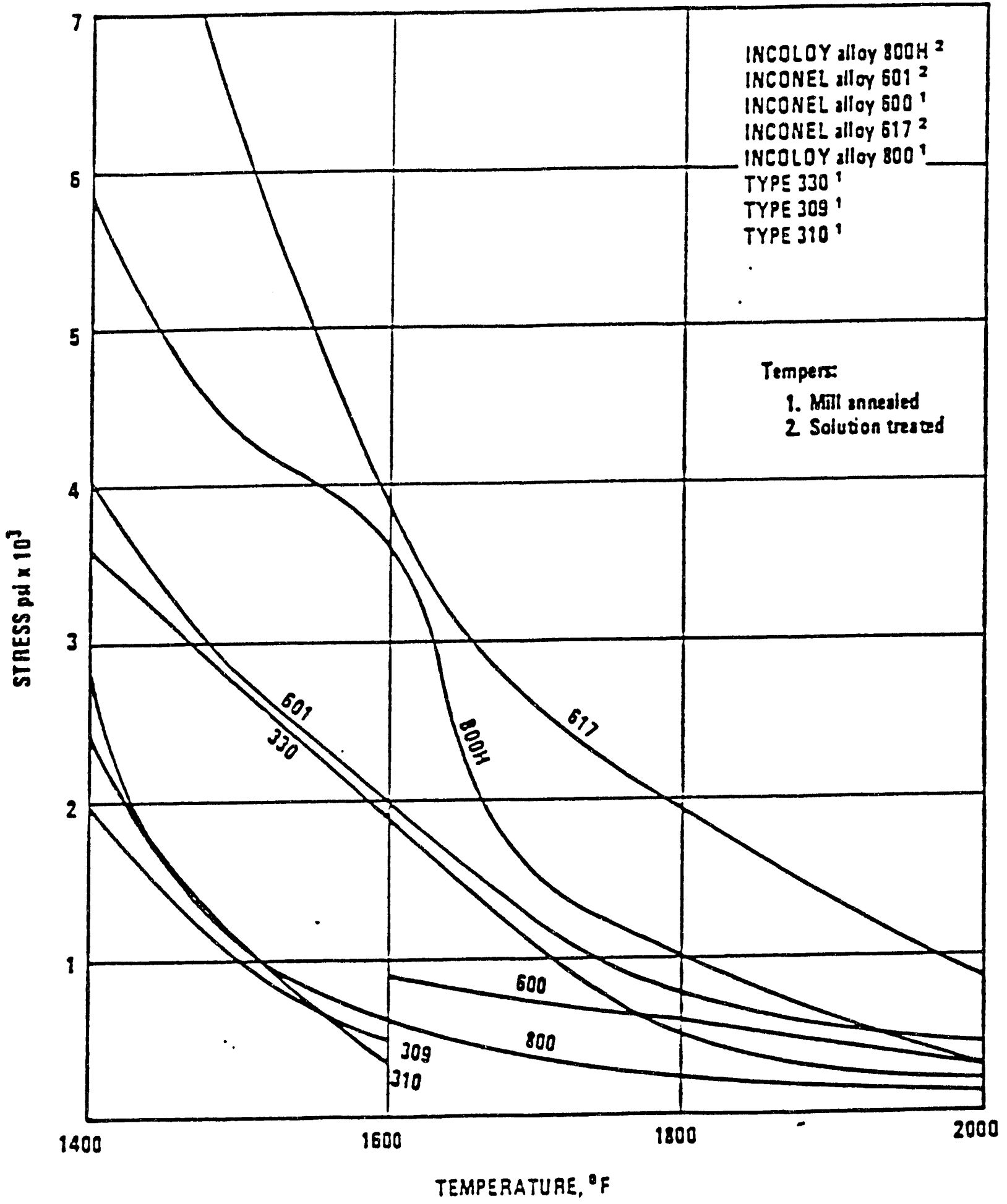

Fig:Ee 5. CREEP DAFA FOR NICKEL-IRON-CHROYIUM ALLOYS OVER

A RANGE OF IEMPERATURES

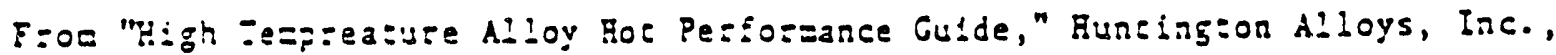
Runc:ng=0r, 170,25720 . 


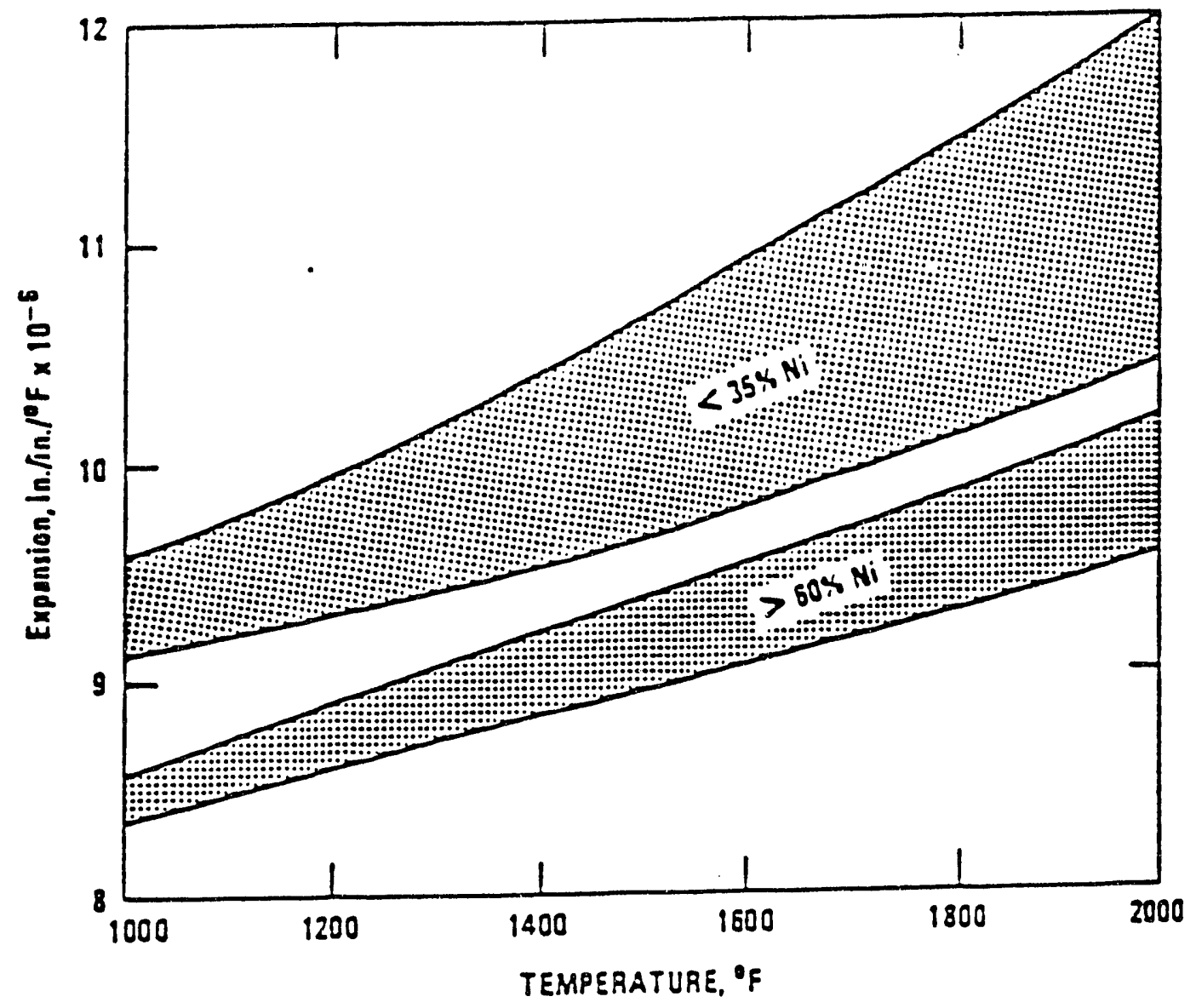

Thermal expansion (bemeen room temperature and temperature shown) of heat-resistant alloys based on the pereent nicxd.

\section{F:GUSe 6. DIAGRAY SHOWTYG THERYAL EXPALISION COEZ:ZCIENIS OF

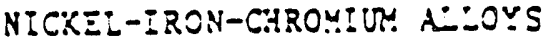

Frod "Kigh Tezpreasure Alloy hoc Pe:Sorance Guide," Hunging:on Alloys, Inc.,

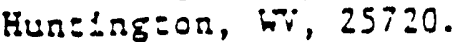




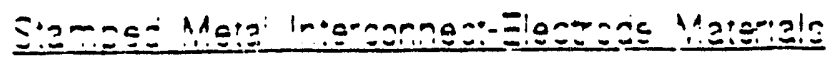

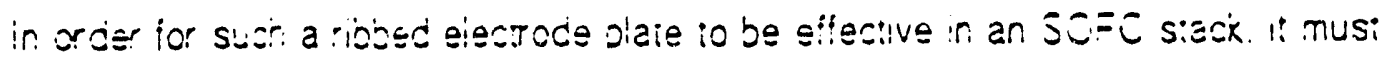

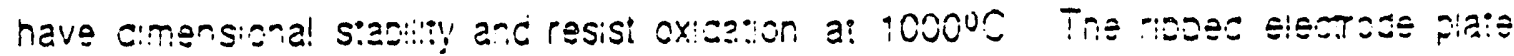
nus: zz: za a z:-

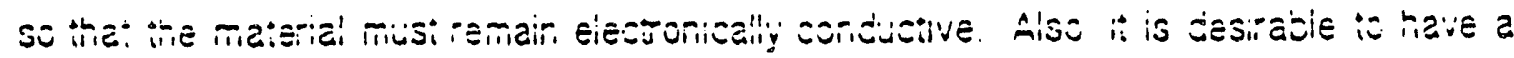

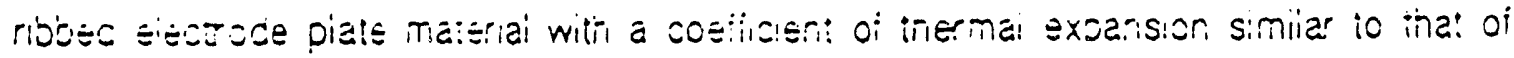
ine z!roon:a slastroly:

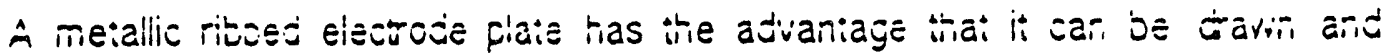
formec into a compiex geometry that will act as a riçi spacer to yieid the neight needed to gei sufiticient coss sectional area ior fuel and oxidant gas tlows. and will not be prone to cacking and catastophic failure tha! could occur if a britile material were utilized. The cilly moderaiely priced commercial alloys which have slow encugh govining scales to be sufficiently passivating at $1000^{\circ} \hat{C}$ are siica-, aiumina-, and chromia-formers. Of these inree. chromia-iormers nave the besi chance of providing sutficiently high elestonis sandusovivity to function sffiestively as a current collestor. A chromiz-former with a suificienit nickel conient is desired to provide the high temperature sterigth ariu resistance necessary so that the separator piate wiil maintain its shape satisfactorily in an operating cell.

Fisure 5 stiows the composition of some reasily availabie and reascriabliy afiociabie (under sijibj alloys in the nicke:-rion-chiomum system. Tabie $i$ iists the compositions of inese alloys.

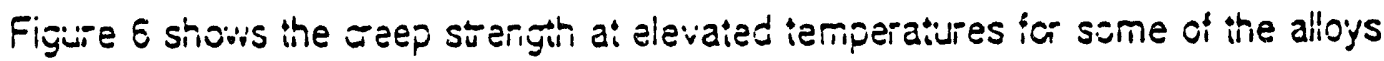
listed in Tabie 1. Figure 7 shows that the magnitude of the thermal coetiicient of expansion of these alloys is dependent on the nickel content.

The ietagonal phase ytura-stabilized zirconia electolyie has a thermal

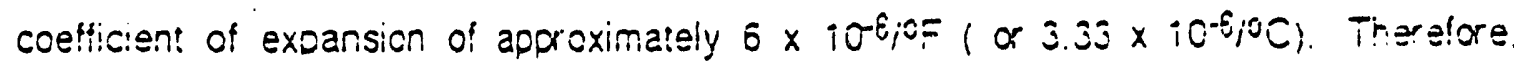
those alloys with geater than $60 \%$ nickel are more like ine zrconia electorye inan

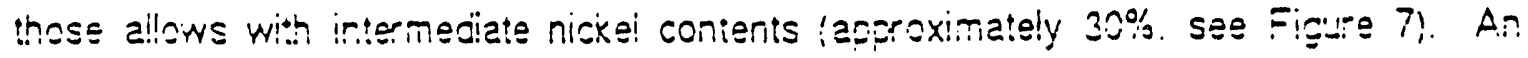

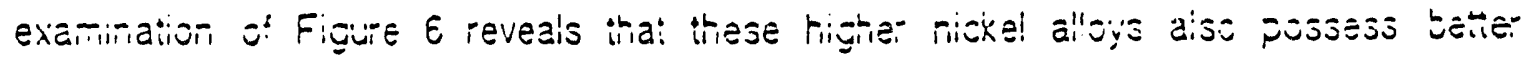
resisiance to ceso a! high tempera!t:e 


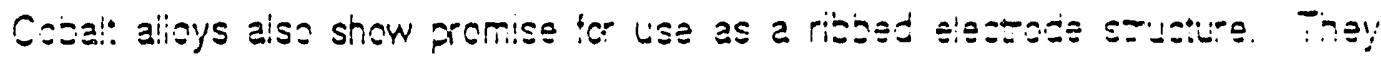

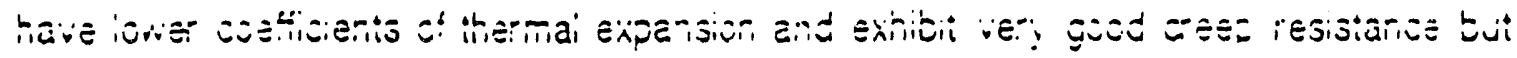
a!e very exp=nsive. Ailoy 617 is a niak res:s:ance as sinown in Fiqure 6 .

\section{Tasis:}

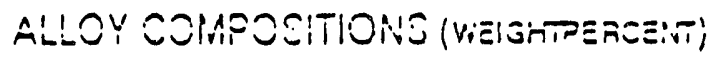

\begin{tabular}{|c|c|c|c|c|c|c|}
\hline & $N_{1}$ & $\mathrm{Cr}$ & $\mathrm{Fe}_{\mathrm{e}}$ & $S_{1}$ & Mn & Ciner \\
\hline & & & & & & $\vdots$ \\
\hline Iricoloy sol & 32.5 & 21.0 & $\angle E .0$ & 0.5 & 0.8 & 0.5 each; $C u, A l . T i$ \\
\hline j30 Siainless & 26.0 & 19.0 & 42.0 & 1.25 & 2.0 & \\
\hline 3i0 Sianless & 200 & 250 & 52.0 & $i .50$ & 2.0 & \\
\hline $30 \subseteq$ Stainless & 14.0 & 23.0 & 50.0 & 1.0 & 2.0 & ! \\
\hline Incone! 6001 & 76.0 & 15.5 & 8.0 & 0.2 & 0.5 & $0.2 \mathrm{Cu}$ \\
\hline Inconei 6011 & 60.5 & 23.0 & 14.1 & 0.2 & 0.5 & $0.5 \mathrm{Cu} .1 .4 \mathrm{~A}$ \\
\hline Incone! 6251 & 61.0 & 21.5 & 2.5 & 0.2 & 0.2 & \\
\hline Incone! 5171 & 54.0 & 22.0 & & & & 12.5Ce. $\cong$ Mo. 1.0A! \\
\hline
\end{tabular}

1 Hunungion Alloys Wesi Virginia

Ci the reastily available, reascriabliy atividable alloj's esnsidered. Inconel Ecol is the most iikely candidate for use as a metaliic separator piate material with solid oxide fue! cells The avallable oxidation cata is avallable for a wide variety of exposure consitions indicating that the depth of oxication should be a few mils fer year of

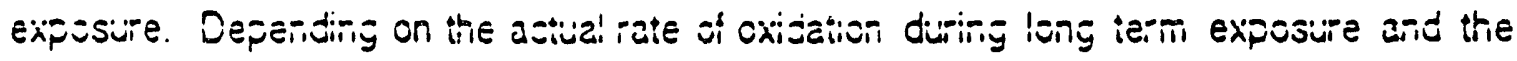
projestec operating life of a celi. the separator piaie may have to be between 20 and 30 inousancins of an incin mick

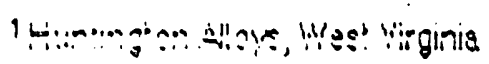




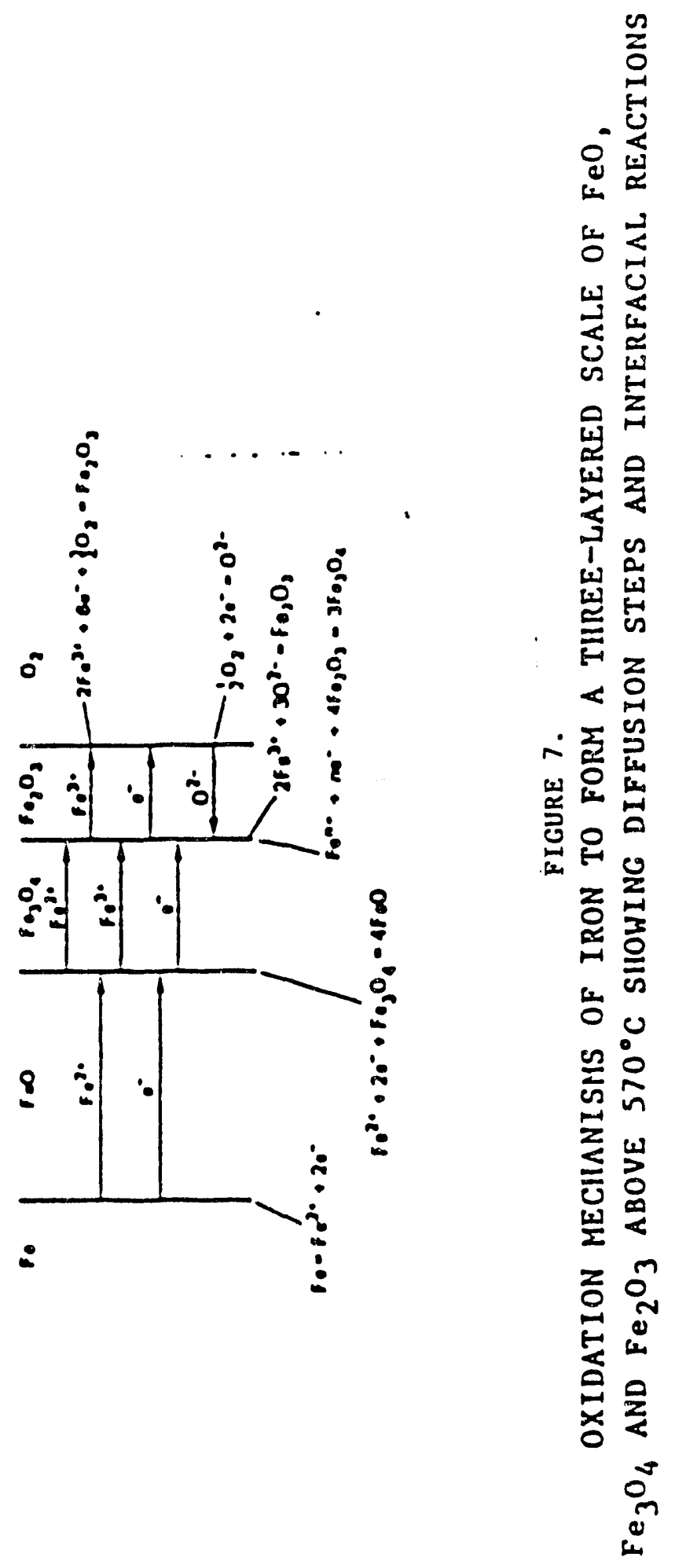




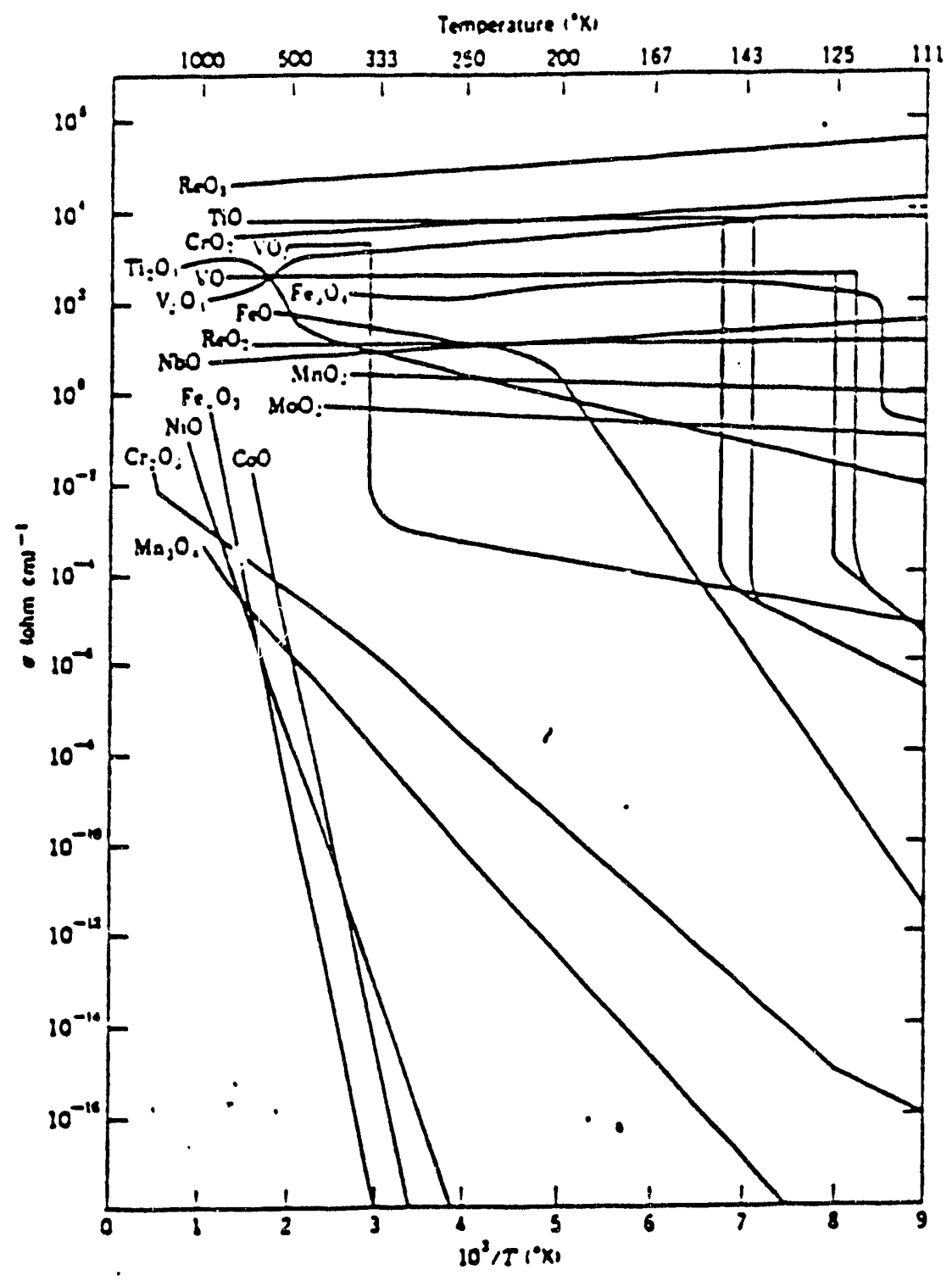

FIGURE 8.

IEYPERATURE DEPEYDENCE OF IHE ELECTRICAL CONDUCIITITY OF SEVERAL ELECTRONICALLY CONDUCIINC OXIDES

(Coustesy D. Adles) 


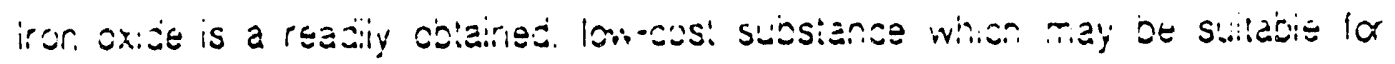

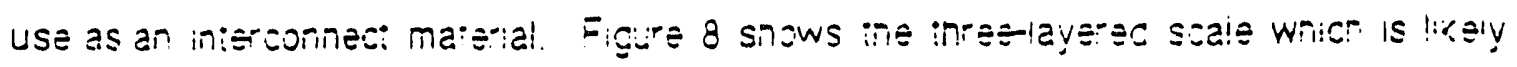

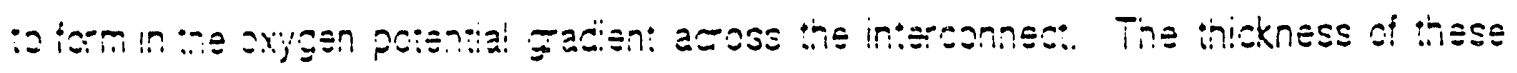
layers dejerid or. the magnitude of the partial pressure of oxygen present in the fuel. gas.

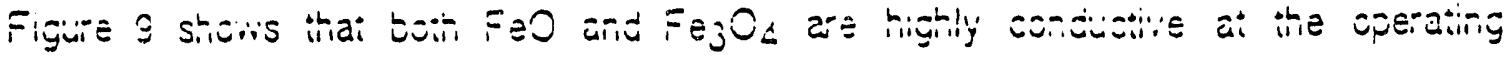

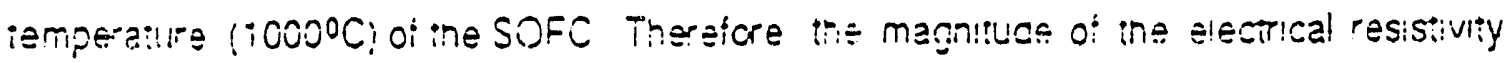
of the rn:econneri woud be deiemined prinarly oy the Fegog laver where the

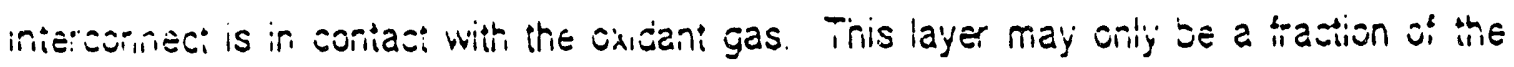
the tc:ai interconnect surface. deperiding on the rate of tansler of oxygen from the eainode gas through the interconnect.

Thus $\mathrm{Fe}_{2} \mathrm{O}_{3}$ is the electically insulating layer in the mut:-lay's iron oxide szale. In the cxidizing environmerii of the cathode gas, the electrical sonsurutiviity of the $F a_{2} O_{3}$ latice could be entianced by doping ine caionic sub-iatice of the oxice with a lower valent cation. The results of some work winich examined the electrica! resistivity oi iron exide doped with Cu, Co. or Min indicates that replacing a traction of the iron with a lower valent cation shouic result in sufficient electrical conductivity to run a series of solid oxide cells a: temperature (10000 C). The electical conductivity and thermal expansion of an in:ersonner. fazricated trom sush a material mus. be sompared tc these of the electolyte

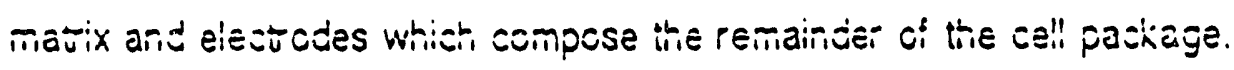

Samples of FeO will be iabricated anc in CTE will be measured. Based on the CTE compatibility. a decision will be made as to whethe: or no: to pursue the alternate FeO ${ }_{\lambda}$ basad concept. Ceramates has airsady obtained a sample of corlugated stainless stes! ( SS 304j for trials as the interconnect. Literature on Inconel alloys is being evaluated and material will be ordered. 


\section{IGTPROGRESS}

\section{Easx Co!! Jesizn Aralus:s}

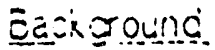

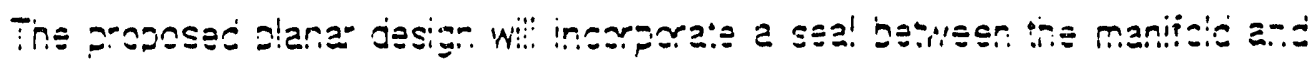

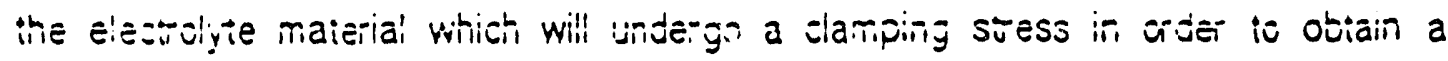
pressure-tight seai The magnitude of this pressure depends on the pressure crop acoss the ce!!. Tha: Is. as the pressure ditierenilai is inceased a higher holding icice miust be apoiled. The pupose of Task 1 is to calcula: azoss the celli ió a given cell corifigurition.

Creep iesis and cell seal evaluaivon. which are to be carree out under Task 7. wi!! yiald inirmation aboli: how stong and gas-tight the saz!s are. These two pieces os informaaion will ihen be utilized as cell design oriteria.

\section{Activites}

No activities in this arez at this time. A summary of resilis was given in the Quarerly Fepcr: covering August 15 through Ustober 31 . 198e.

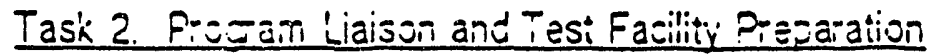

\section{Eackgound}

This iask invivies the design and constuvtion of iest equigment whitivi are ic be usec ic les: SOFC compcrients in Tasks 7 . 6 . and 9 . There are three iypes of lesis to be carriec ou: under this contac: these are.

- Cresz testing ó singla or multipie SOFC componenis

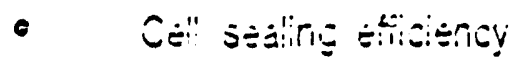

- Comale sei! iesis. 


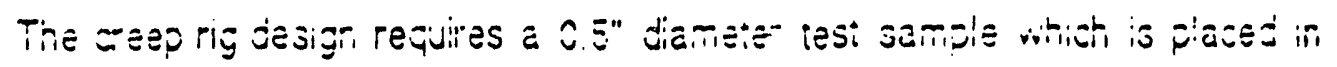

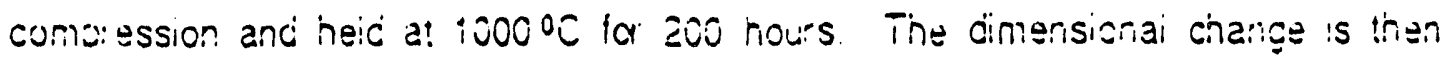

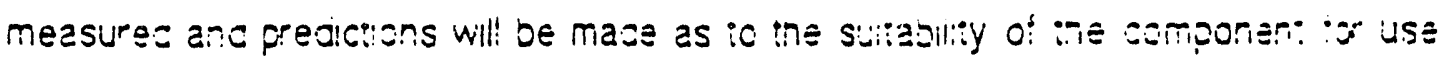
in :t: $\Sigma=0=0$.

\section{Acivites}

Same mince resssign ot the zosp rig vas caried out gurng this periad.

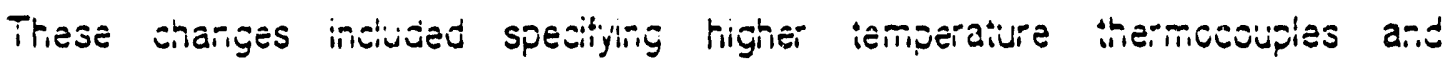
impienentation of a dia: indicator in coniunction with the kaman meter.

Work has begun on the design of the celi seal or cell iesting equipment. Design ariteria for the cell seal evaluation rig were recently discussed during a visit of GT siaff to Cerama!es.

\section{Task 7. Cut-of-cel: Tests}

\section{Activities}

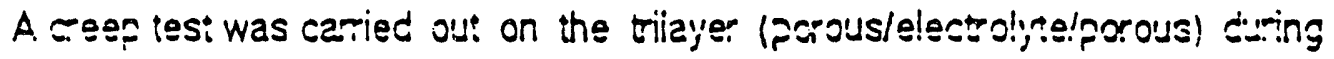
this repunting period. This iest ran for 74 hours betore thermosoujite failure stiut down the test. then restarted and run for an accitional 125 hours. A compitite discussion of ine creap ies: is included below. Creep under compression was measured at $1000^{\circ} \mathrm{C}$ with a loadsd area of approximately 0.25 square insh. A compressive load of 50 psi was used.

The resul: indicates that the primary creep was on the ooder of $031 \%$ and ccsured within the ifis: 5 hours of testing. The zeep rate atter tinis point appeared to te $O$ within the limits of ressiusion of our equiprient.

\section{Opiecive}

Measure the שeep rate uncer compression of the solid sxide fual esll componen:s. in this case the :rilayer stuciure 
Insoginginn

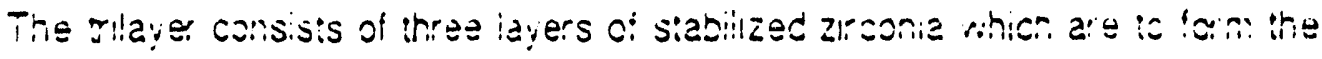

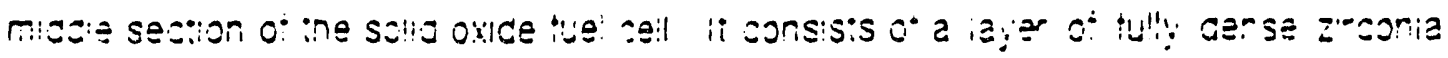

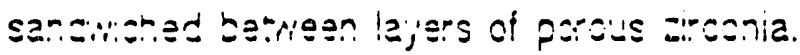

Since this comizonent will be plazed uncer compression. ine ceformation

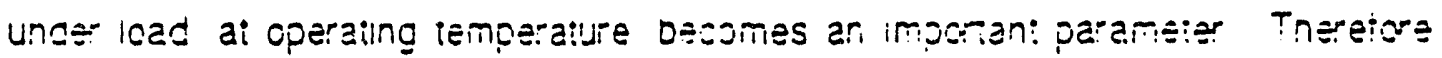

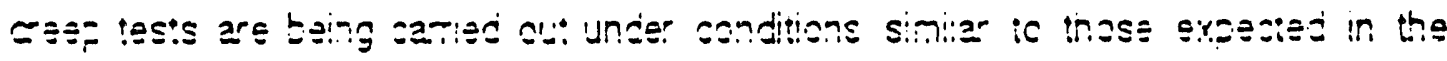

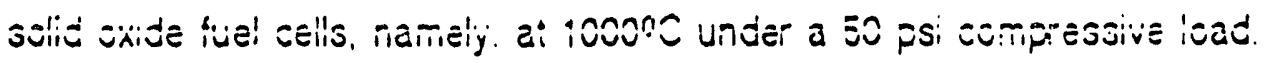

\section{Exoerimental Drosedure}

The samples were received as nori-equillateral hexagunal pieses, from Ceramates Lot FojosiciFT. Because of the irregular shape. the area was measured by racing the shape onto a paper and cuiting out. This was then compares to the weight piece of the same paper with a known area.

Thickness was measured in seven piaces and averaged (see Tabie 2). Five samples were placed on iop of each other and glued logether. The siacking was reguired :o cbtain sutifien: thickness to be vithin tive resoliditon of the tesi rig. This yieicied a ictal sample itivininess of äound 1 ic milis.

This sample stack was then placed between two alumina eylinders and held with under a low load. The ilunace was brought up to $10000 \mathrm{C}$ a: about $4^{\circ} \mathrm{C} / \mathrm{min}$ and allowed io siabilize. A compressive load of 50 psi was ther applied and held ior it hours, then restarted and run out 125 more hours Changes in the thickness of the sample siack were measured in the ceep rig and recorced Atier lesing. the samples wera removed and the thickness of each iest piece was then measured in sever plasss as was done prisin io testing.

\section{Gesul:s}

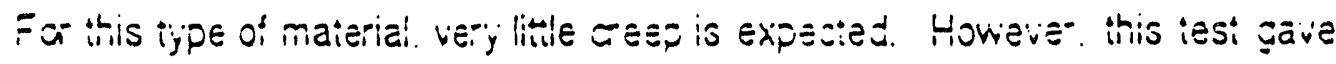
an cosortunity ic iss: our apoa: atus and verify that this is the cass the resuits of inkxาes: measuremen!s detore arid atter ine 74 roure ies: snowez ina: inere was 


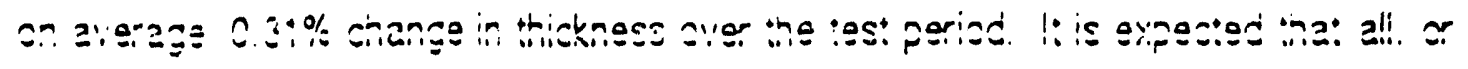

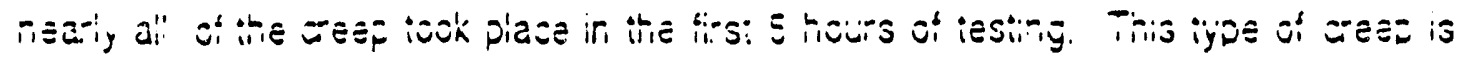

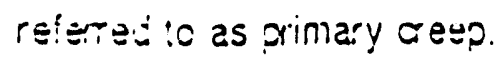

The plo: of shange in thickness verstus ime shown in Foure 10 indica:es that

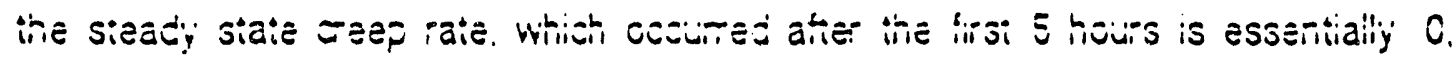
vitimin the imit of our resolution. Thus the rilaye materla! will mos: ikely no: cause

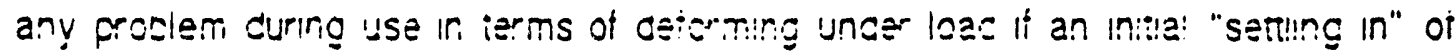
iess tian $0.3 \%$ is az:ommoza!:

The creep ra!e from 74 10 20 J hours appeared to be zero. within the limits of resoluition of our equipment. Tn!s was also incicated by. the pre and pos:-test thickness measurements shown in Table ? where the change in thickness trom 74 to 200 hours was essentially zero.

Table 2

RESULTS CF CREEP TESTING OF ELECTAOLYTE TRILAYER MATERIALL PC3848CFT

(Samples were measured before and atier testing for 74 hours and then tested out to 200 hours a: $10009 \mathrm{C}$ under 50 psi sampressive load.)

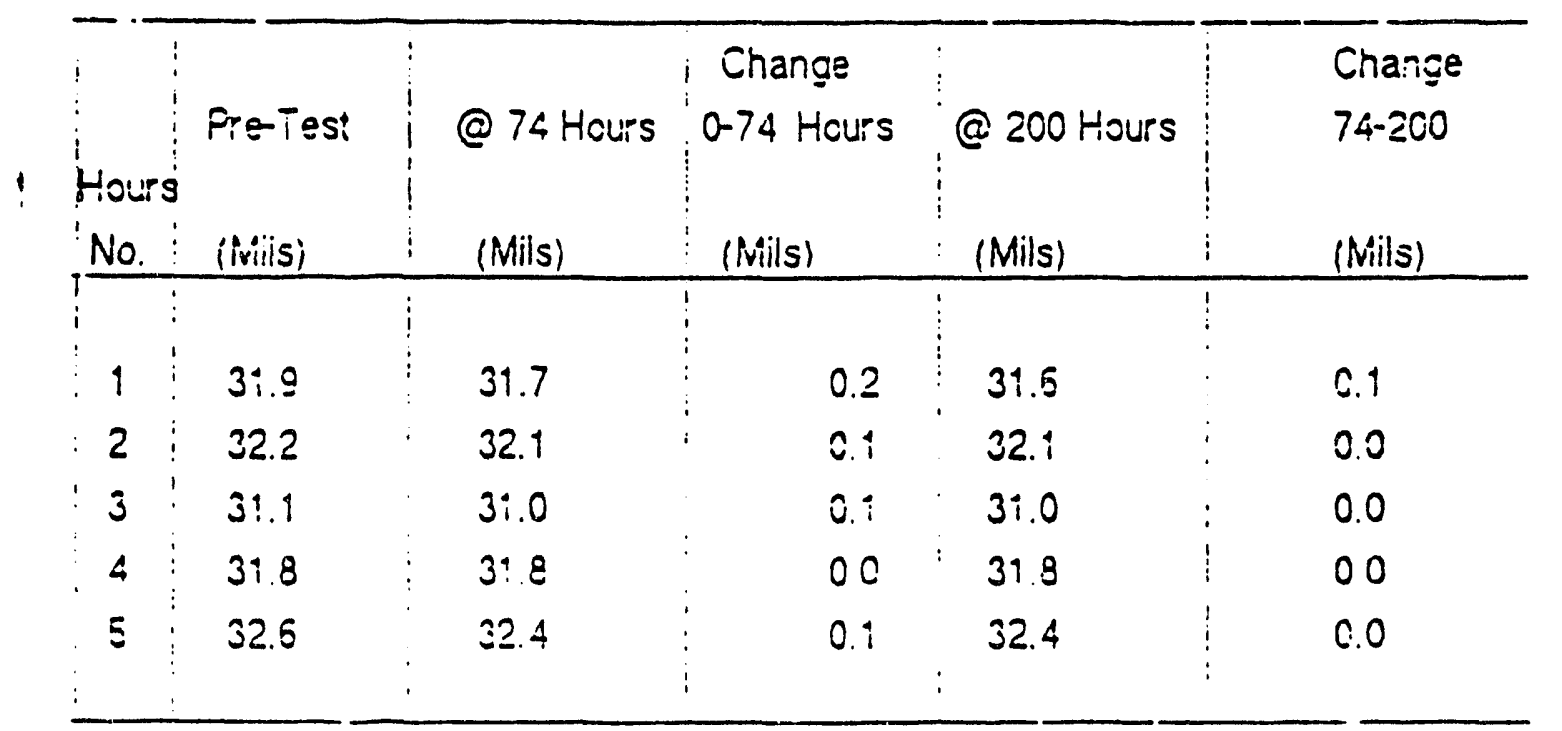




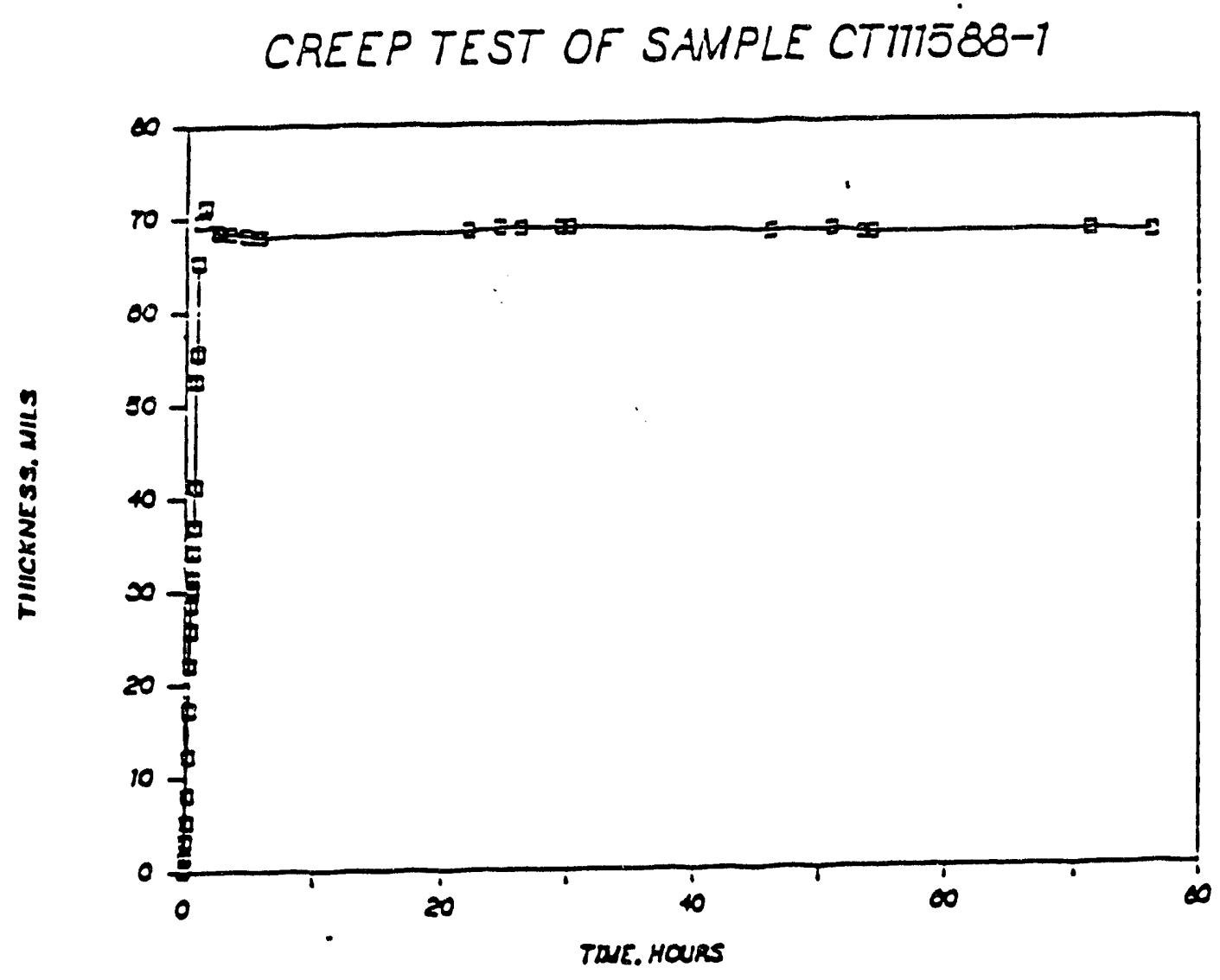

FIGURE 9.

IHICRVESS CRUNCE VERSUS IIYE FOR ELECTROLYIE IRILAYER MATERIAL PC3848CFT (Iested at $1000^{\circ} \mathrm{C}$ under 50 pst coupressive load)

(MR65079NOV/RPE: :d) 


\section{Tasrs 9-11}

These tasks were noi active durng this reporting period. 


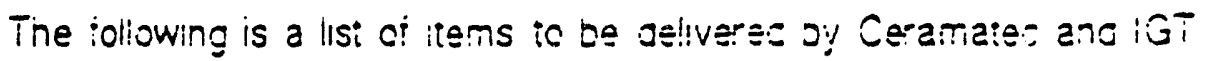

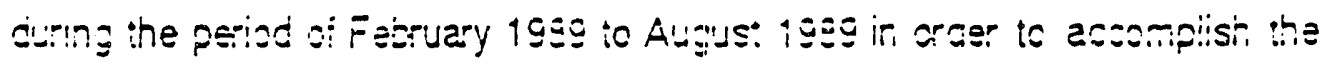
goals of the SOFC pisgam.

FEBRUARY

Cstanate:

- Schemiailc of proposed cell design to IGT.

- Cieñ Sample CRP-2 to IGT: Lilajei + Giass seai mizierial.

$\underline{1 G T}$

- Design of the Cell Seal Evaluation (CSE) rig using schematic referred to above.

\section{MARCH}

\section{Ceramates}

- Creep Samples CRP-3 and CPP.4 to IGT: trilayer + anode. trilayer catitude

IGT

Order pats for CSÉ rig

- Run cosf ies: on Samp!e CFP-2. da:a to Ceramaiec 
APRIL

Geramatec

- CSE SampiE CSE-1 ic IGT.

$\underline{\text { GT }}$

- Bui: CSE rig

- Run ceep test on Sample CAP-3 and CRP-4, data to Ceramatec.

MAY

Ceramatec

- Creep Sample CRP-5 to IGT: interconnect sample.

IGT

- Run CSE test on Sample CSE-1.

JUNE

Ceramatec

- CSE Sample CSE-2 to IGT.

IGT

- Run creep test on CRF-5. data to Ceramates.

JULY

Equmatec 
T:

- Fun CSE-z data to Ceramatsc.

AUGUST

Ceramatec-IGT.

- Mieeting :o oissuss tes: result:s and tinal ce!! des:gn of SOFO tes: ce!!. 

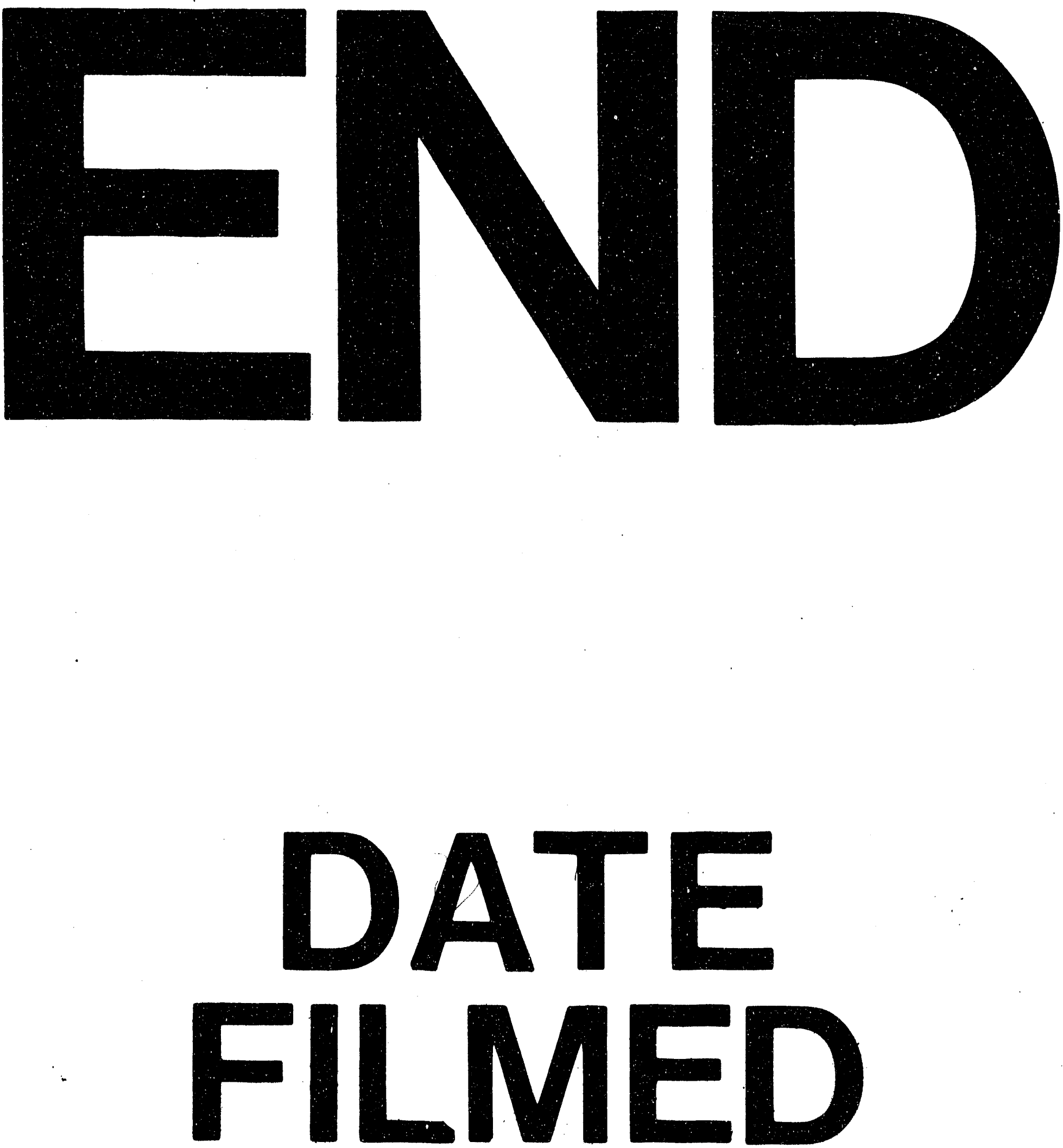

1
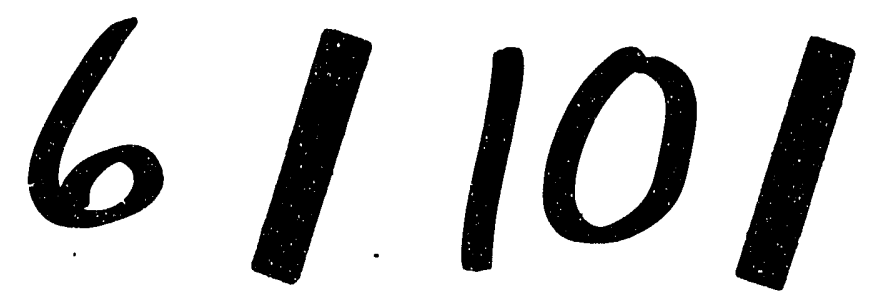

93 
